\title{
Access and appropriation of journalistic news on social networks in Brazil: Refining the notion of "participation"
}

\author{
Telma Sueli Pinto Johnson \& Pedro Augusto Farnese \\ Universidade Federal de Juiz de Fora - UFJF, Brasil \\ E-mail: tjohnsoneglobo.com/sjohnsoneglobo.com
}

\begin{abstract}
This article examines forms of appropriation and mediated deliberation of news on the page of the centennial Brazilian newspaper $O$ Estado de $S$. Paulo accessed through the global social networking platform Facebook. The study focuses on interactions among users from the point of view of quality of participation, going beyond common practices of (dis)liking and/or sharing. Comments to news articles posted by the newspaper are taken as a more active and detailed kind of participation for exchanging public communication argued by reasons. A comparative corpus of analysis was selected in the months of October 2015 and October 2016, totaling

tand and differentiate valid and responsible forms of participation able to construct and sustain democratic debate. One of the main findings was that 185 posts of the Estadão newspaper in our studied period of October 2015 generated 1,195 comments, but only $38 \%$ of these comments were considered to be qualified ones. One year later, data revealed completely different evidence. Although there were more posts on the Estadão page on Facebook, totaling 201, there were considerably fewer comments. Participation is discussed within the troubled political context and its relationship with the dramatic economic recession in the country.
\end{abstract} 386 posts and 1,911 comments, in order to unders-

Keywords: journalism; social networks; issues of participation.

\section{Acesso e apropriação de notícias jornalísticas em redes sociais no Brasil: refinando a noção de "participação"}

\section{Resumo}

Este artigo examina formas de apropriação e deliberação mediada de notícias na página do centenário jornal impresso brasileiro O Estado de S. Paulo acessada pela plataforma de rede social global Facebook. O estudo foca nas interações entre usuá- rios sob a ótica da qualidade da participação, para além das práticas comuns de curtir, descurtir e/ou compartilhar. Os comentários aos artigos de notícias publicados pelo jornal em sua página do Facebook são considerados como uma participação mais

Data de submissão: 2017-11-03. Data de aprovação: 2018-04-26.

A Revista Estudos em Comunicação é financiada por Fundos FEDER através do Programa Operacional Factores de Competitividade - COMPETE e por Fundos Nacionais através da FCT - Fundação para a Ciência e a Tecnologia no âmbito do projeto Comunicação, Filosofia e Humanidades (LabCom.IFP) UID/CCI/00661/2013.
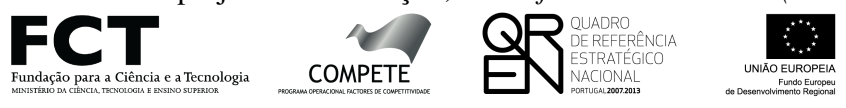

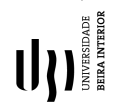

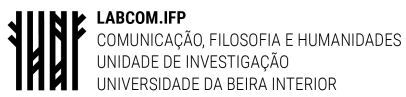


ativa e elaborada para trocas comunicacionais públicas argumentadas por razões. Um corpus comparativo de análise foi selecionado nos meses de outubro de 2015 e outubro de 2016, totalizando 386 postagens e 1.911 comentários, para compreender e diferenciar formas de participação válidas e responsáveis capazes de construir e sustentar o debate democrático. Uma das principais descobertas foi que 185 postagens do Estadão no período estudado de outubro de 2015 geraram 1.195 comentários, mas apenas $38 \%$ desses comentários foram considerados qualificados. Um ano depois, os dados revelaram evidências completamente diferentes. Embora houvesse mais postagens na página do Estadão no Facebook, totalizando 201, houve consideravelmente menos comentários. A participação é discutida dentro do contexto político problemático e sua relação com a dramática recessão econômica no país.

Palavras-chave: jornalismo; redes sociais; problemática da participação.

\section{INTRODUCTION}

THE growing access and consumption of news on social networks is a global phenomenon. 1 Recent data from the Reuters Institute for the Study of Journalism (Digital News Report 2016) indicate that $51 \%$ of the 50 thousand focus group interviewees from 26 countries used social media as a news source each week. Facebook was the most widely accessed network platform for finding, reading, watching and sharing news.

The report identifies, in the scope of countries researched, that Brazil has one of the highest use of social media as a news source. The data for Brazil show the specificity of being representative of the behavior of news consumers in urban areas. The Brazilian population of 204.5 million inhabitants, with $58 \%$ of whom have access to the internet, is represented in a sample of 2,001 respondents.

The phenomenon of high rates of access and consumption of news through social networks by Brazilians is not explained qualitatively by the report. Carro (2016), however, correlates between the loss of readership in nine of the ten newspapers with the largest print circulation in 2015, with a 50\% increase in the use of online news in the first half of 2015 when compared to the same period of the previous year.

A closer look at the data leads us to question what Brazilians do with the journalistic information accessed on social networks. Thus, the present study parts from the findings of the Reuters Institute to further investigate ways of news appropriation by Brazilian users of Facebook. Our primary focus is to explore issues of quality participation, since online social networks allow consumers to interact and act on the content provided.

Practices of use and appropriation of media content in different contexts, individual and collective, deserve to be looked at through social and historical perspectives. Participation is taken for granted in these times of digital cultures, but it is necessary to delineate forms and degrees of participation. We propose, when studying interactions among news readers on social networks, comments to be valued as more active and detailed forms of participation, rather than simplistic and automatic choices of likes, dislikes and shares.

Notions of human communicative interaction (Primo, 2007; Rost, 2014) are articulated with the criteria of public exchanges supported by reasons (Gomes, 2014; Gomes and Maia, 2008; 
Habermas, 2003) to ask the research question: "How do Brazilian users of Facebook appropriate journalistic news beyond the common practices of (dis)liking and/or sharing?" Although it may seem redundant, we apply the term journalistic news as a distinction between journalism and other knowledge-producing professions (Carlson and Lewis, 2015).

In order to answer the question, informative and editorial articles which produced the most comments were selected among visitors of $O$ Estado de S. Paulo (which we shall henceforth refer to as Estadão) newspaper's page on Facebook. Estadão was founded in 1875 and first published its online edition in 1995. Its page on Facebook was monitored on two different occasions, 12 months apart, in the years of 2015 and 2016, totaling a comparative analysis corpus of 386 posts and 1,911 comments.

The first data collection took place on the weekdays of the $14^{\text {th }}, 15^{\text {th }}$ and $16^{\text {th }}$ of October 2015 after research by the North American company Bites indicated the paper to be that with the most power of internet engagement in Brazil (Portal da Imprensa, 2015). The second took place on the weekdays of the $17^{\text {th }}, 18^{\text {th }}$ and $19^{\text {th }}$ of October 2016 , in order to maintain a reasonable period of time related to the first data collection, but also to avoid major influences due to regional election campaigns across the country at that time.

\section{CONSUMPTION OF NEWS ON SOCIAL NETWORKS}

The discussion about the forms of access, consumption and appropriation of news on social networks is relevant in a scenario in which increasingly more sophisticated algorithms become ubiquitous in mediating the discourses and flows of human knowledge (De Santi, 2015; Gillespie, 2014). Wooley (2016) defines social algorithms - as opposed to general search, browse and recommendation algorithms - as a particular type of automated software designed to collect information, make decisions, interact and imitate real online users.

One of the malignant aspects of digital automation in social networks is that this type of robotization is being used for political ends. As Wooley (2016, p. 2) explains: "The key feature of this variety of bots is not where they live, i.e., on a particular platform, but what they do, i.e., gather and sort information." In line with an international literature that is still under construction, the author argues that social algorithms are widely used as a resource to manipulate public opinion on social sites such as Facebook and Twitter.

In order to advance to a construct about forms and degrees of participation mediated by contemporary technology, considering the possibilities of socio-politically manipulative algorithms, the methodological strategy of this study was to observe and save in a data bank, built for the purpose of this research, all news articles posted by Estadão in October 2015 and in October 2016. At the same time, screenshots of likes, dislikes, shares and comments were stored and categorized as forms of users' participation.

Next, news posted by Estadão which generated more comments than shares were selected, for the purpose of analyzing the comments against the background of validation and argument criteria justified by reasons. One of the bases of this classification includes the categorization applied by the Digital News Report 2016 to forms of engagement in access and consumption of news through social networks. An active participant is deemed to be one who reads, shares and comments on 
news, while a reactive participant reads and shares but does not comment and a passive participant reads but does not share or comment.

Another supporting argument for this classification was the investigative report published by the Superinteressante magazine entitled The dark side of Facebook (De Santi, 2015), which revealed likes to be a sort of social currency in the network, charged monetarily, following the logic of the algorithms.

In the academic literature, there is a tradition of studies on the relationship between the social construction of the technology and the capitalist spirit known as Social Construction of Techno$\operatorname{logy}$ (SCOT). A recent systemization of this tradition was presented by Mager (2011) at the A Decade in Internet Time conference held by the HUMlab, at Umea University (Swedeb). Going beyond a review of the literature, Mager's (2011) empirical studies suggest the need for a change in focus on the impacts the search engine has on society regarding social practices and the power relationships involved in constructing these mechanisms based on the ideology of the algorithms.

We agree with Mager (2011, p. 13) in stating that

This shift of perspective enables us to understand that search technology, as every other technology, could be otherwise. If website providers or users broke out of the core network dynamic, the power of the search engines and their schemes of exploitation would fall apart. If mass media and activists initiated a more critical debate about search engines and the myriad of data they collect, store and process, big players such as Google would be destabilized.

Although Mager worked with the Google search engine as the empirical object, we consider in our study both search websites and social network platforms to be sophisticated databases, constructed in architecture of flexible relationships, enabling them to be quickly fed, as well as to quickly filter and recover information, automated by algorithms (Woolley, 2016). Recognizing these tools as patterns of computational mathematical logic (Manovich, 1999) does not, however, prevent us of being able to differentiate between the terms database and algorithm (Gillespie, 2014) as structures that, although functioning together in practice, can be analyzed separately from a sociological perspective.

Thus, we are interested in learning and understanding social appropriation of technology from the point of view of news consumption via Facebook in the Brazilian context. The investigative story published by De Santi (2015), The dark side of Facebook, gives us certain clues for constructing a pilot model of the proposed methodology for collecting and analyzing hybrid (qualiquantitative) data. De Santi (2015) tested the Facebook algorithm over several months, setting up four different, empty pages with no content whatsoever posted.

In the comparison, the journalist observed that when there is payment to boost the posts, the algorithm produces a lot of feedback. On one page, the journalist paid 20 Reais in exchange for likes, receiving 69 likes within 24 hours. On another page, De Santi received 167 likes after paying Facebook 96 Reais. It is suffice to say that in 2015 the monthly minimum salary in Brazil was 788 Reais (roughly equivalent to 200 Euros).

For De Santi, what was most revealing was that, on entering into contact, using his real name, with those who had liked the pages, in order to discover the reason for this action, he received 
garbled, disjointed messages, leading him to conclude that they had been automatically produced by the algorithm. As he revealed

One or the other responded, always following the same unenlightening pattern: "There was nothing to like, but I liked it anyway.” I became dejected until, for some reason, Facebook began to prevent me from sending paid messages. He ceased to earn a few reais - and I lost my only way of contacting those who had liked my false pages. Apparently, at least some of them were real people, not robots programmed to click. As to why they 'liked', we will never know. (De Santi, 2015, p. 39).

The mystery raised by De Santi, as well as the increasing cross-over of algorithm logic into public life is just a part of the multiple dimensions of the phenomena of mediated communication. Mitchel and Hansen (2010, p. XII) observed that media as a collective singular noun is somehow tied to the emergence of the mass media - from the eighteenth century's investment in paper as the medium of circulation and sociality, to the nineteenth century's invention of electricity as the medium of phenomenality, to the newspapers of the late nineteenth century and the television of the twentieth, forms through which information itself is mediated.

Mitchell and Hansen's reflections are relevant as they draw attention to the perspective that studies of the media cannot restrict themselves to studying the means of communication as technologies per si, in a deterministic way, but should be open to studying the fundamental rationality between man and technique (Stiegler, 2010) as an irreducible function of mediation in human history. As Mitchell and Hansen explain (2010, p. XII), medium as a term "designates a minimal relationality, a minimal openness to alterity [...], that appears somehow central to our understanding of ourselves as 'essentially' prosthetic beings."

This broader notion of media is of particular interest, as a backdrop to this study, for the possibilities of reflection and analysis of empirical work under the notion of mediation and mediatization. It is noticeable that the amplitude gained by the notion of mediation in the communication studies (Martino, 2015) of recent decades makes its heuristic value and analytical yield difficult. However, Silverstone (1999) attributes a generic and strongly de-singularizing character to mediation as well as the lack of explicitness of the political, economic, aesthetic and technical determinations.

For Silverstone (1999), one must think of media as processes of mediations, circles of meanings. We agree with the author in a sense that mediation is infinite, constructing, reaffirming and discontinuing frameworks of representation and experience, as an unfinished interpretive process, constantly becoming. "It implies the constant transformation of meanings, on a large and small scale, important and unimportant, as media texts and texts about the media circulate in written, oral and audiovisual form, and as we [...] collaborate in its production." (Silverstone, 1999, p. $33)$.

Relating media with the political process, Silverstone (1999) observes that in the new media environment, overloaded with information and a multitude of voices that confuse the boundaries between the public and private spheres, effective participation seems to have disappeared. The author challenges the contemporary role of media institutions: "What is in question is the capacity 
[...] to create and sustain significant public debate: in a justifiable, accessible and responsible way. We cannot ask for less, nor should we expect it." (Silverstone, 1999, p. 273).

On a conceptual course that tries to account for the role played by the institutions and processes involved in mediated communication, Ramirez (2016) argues that despite the diverse, disjointed approaches to mediatized phenomena, they all include communication as a key element. Ramirez (2016, p. 17), therefore, proposes the concept of mediatization to express the centrality of communication technology and processes pervading economic and political life and permeating the universe of values and representations nowadays.

Although Ramirez's notion of mediatization emphasizes the mediatic centrality for interpreting the becoming of contemporary society, the proposal rejects deterministic readings, considering that mediatization "establishes shapes and captures flows" (2016, p. 17). In this way, Ramirez's (2016) view is linked with that of Hjarvard (2012), who understands the mediatization of society as the process through which human relationships and social practice are linked with the media, becoming routine practices. "Contemporary society is permeated by the media, to an extent that the media may no longer be conceived of as being separate from cultural and other social institutions.”(Hjarvard, 2012, p. 54).

\section{METHODOLOGY AND ITS STRATEGIES}

Media, mediation and mediatization were used as conceptual tools to aid in an empirical approach of the forms and degrees of quality of participation, through comments on the Estadão Facebook page, in order to answer our research question - "How do Brazilian users of Facebook appropriate journalistic news beyond the common practices of (dis)liking and/or sharing?"

The central methodological strategy was to let the categories of analysis emerge naturally from the research corpus themselves, reflecting the atmosphere of economic crisis, widespread demonstrations and political polarization in the Brazilian context.

During the first stage of collecting the data of the Estadão posts, on the $14^{\text {th }}, 15^{\text {th }}$ and $16^{\text {th }}$ of October 2015, the scenario in Brazil was one of strong political unrest between the political parties PT (Workers' Party) and PSDB (Brazilian Social Democrats' Party) which marked the 2014 presidential election campaign. The dispute between the then-president Dilma Rousseff (PT), up for re-election, and senator Aécio Neves (PSDB) took place at a time when the performance of the Brazilian economy was weak, following years of economic growth under the PT government of President Lula (2003-2011).

As a backdrop, during this period of the research, two relevant issues to social life in Brazil appeared:

- The judgement of the Federal Supreme Court on the process known as the "Escândalo do Mensalão" - political corruption through vote buying between 2005 and 2006 by members of the National Congress of Brazil, the main actors in which were certain members of Lula's government, members of the PT and of several other political parties;

- The operation Car Wash investigations, began secretly in 2013 and was officially launched by the Brazilian Federal Police on March 17, 2014, then in its $21^{\text {st }}$ stage, with the 
imprisonment of dozens of doleiros (black market money changers), executives of shell companies and high-level managers at the state-owned Petrobras company.

During the second stage of collecting data for the research, a year later (on the $17^{\text {th }}, 18^{\text {th }}$ and $19^{\text {th }}$ of October 2016), the Car Wash operation was then in its $35^{\text {th }}$ stage, revealing Brazil as a country drowning in systemic corruption. At that moment, the Federal Police had then carried out more than 1,000 search and seizure and temporary and preventive arrest warrants and witness' summons in the investigations into money laundering, organized crime, obstruction of justice, fraudulent currency exchange and bribary.

In this panorama of worsening political, economic and institutional crisis, three other issues stand out in order to understand the atmosphere of the comments and quality of participation on the Estadão Facebook page:

- The impeachment process against President Dilma Rousseff, which had begun on December 02, 2015 in the Chamber of Deputies, came to an end on August 31, 2016 with the revocation of her mandate amidst allegations of non-compliance with the Budgetary and Misconduct in Public Office Laws. The president was suspended following a vote in the Senate on May 12, 2016, with vice-president Michel Temer taking over her duties in the interim before assuming the position definitively;

- In September 2016, a month before the second stage of the research, the unemployment rate hit $11.8 \%$, affecting 12 million Brazilians. In 2016 alone, a total of 1.3 million workers lost their jobs;

- During the second round of data collection on the weekdays of the $17^{\text {th }}, 18^{\text {th }}$ and $19^{\text {th }}$ of October 2016, Brazil was in between regional election campaigns nationwide. The election day on Sunday October 2, following the Brazilian electoral legislation, had a run-off on Sunday October 31. As a strategy of research, we maintained a reasonable period of time related to the first data collection but also tried to avoid major influences due to election campaigns across the country.

\section{ANALYSIS AND DISCUSSION OF RESULTS}

The mapping concentrated on cases in which the comments exceeded the number of shares, with the aim of filtering them for the analytical corpus of the proposed methodology. The October 2015 monitoring identified 185 Estadão posts, and 201 further posts were identified in the October 2016 monitoring, totaling 386 publications placed into circulation on Facebook by the paper.

In the stage of classifying posts, the constructivist tradition of journalism studies was used to define hard and soft news (Silva, 2013; Sousa, 2002; Wolton, 2010). As this study is part of a research project underway since 2014 (Johnson, 2015; Johnson and Pereira Jr., 2015), we returned to the concept of facts as newsworthiness and news-values as criteria of selection and hierarchy influenced by technical and ideological aspects.

In general, we categorized news-values involving hard news as: impact; conflict; controversy; proximity; government; drama/tragedy; shock and justice. The soft news categories included entertainment; curiosity; knowledge and rarity. An extra category, "other", was criated to cover items which did not fit into either the hard or soft news categories due to lack of clarity of the 
contents that could only be understood by clicking on the subtitle that remediated the content to the newspaper's website.

Table 1 shows the general comparative results of the findings based on the quantitative and qualitative data, for the two stages of the investigation, which totals 386 posts and 1,911 comments by users.

Table 1. Comparative analysis corpus of Estadão on Facebook 2015/2016. (Self-elaboration)

\begin{tabular}{|c|c|}
\hline Stage 1 (October/2015) & Stage 2 (October/2016) \\
\hline $\begin{array}{l}185 \text { posts (daily average of } 61.6 \text { publications) - } \\
49 \% \text { soft news, } 47 \% \text { hard news, } 4 \% \text { other. }\end{array}$ & $\begin{array}{l}201 \text { posts (daily average of } 67 \text { publications) - } \\
55 \% \text { hard news, } 39 \% \text { soft news, } 12 \% \text { other. }\end{array}$ \\
\hline Posts with more comments than shares: & Posts with more comments than shares: \\
\hline 30 (16.2\% of the total) & 58 (28.8\% of the total) \\
\hline $\begin{array}{l}\text { Of which: } 21 \text { soft news (70\%), } 09 \text { hard news } \\
(30 \%)\end{array}$ & $\begin{array}{l}\text { Of which: } 37 \text { soft news }(\mathbf{6 3 . 8 \%}), 21 \text { hard News } \\
(36.2 \%)\end{array}$ \\
\hline Post with the highest number of comments: & Post with the highest number of comments: \\
\hline $\begin{array}{l}\text { Title: "Well, that was stupid" - the subtitle of the } \\
\text { post contextualizes the case of a cleaner who ate } \\
\text { the sweets of the Chief of Federal Police in Ro- } \\
\text { raima state }(14 / 10 / 2015)\end{array}$ & $\begin{array}{l}\text { Title: "Students handcuffed by municipal po-- } \\
\text { lice in protest against the minister of education" } \\
(18 / 10 / 2016)\end{array}$ \\
\hline Category: Hard news & Category: Hard news \\
\hline Total comments analyzed: 468 & Total comments analyzed: 377 \\
\hline Disqualified: 357 & Disqualified: 15 \\
\hline Qualified: 111 & Qualified: 362 \\
\hline $\begin{array}{l}\text { Post with the second highest number of com- } \\
\text { ments: }\end{array}$ & $\begin{array}{l}\text { Post with the second highest number of com- } \\
\text { ments: }\end{array}$ \\
\hline $\begin{array}{l}\text { Title: "For the chief of Federal Police, the Sweets } \\
\text { case was a breach of trust" }(15 / 10 / 2015)\end{array}$ & $\begin{array}{l}\text { Title: "Jon Bon Jovi can't stand singing hits like } \\
\text { Livin on a Prayer anymore: 'It depresses me"” } \\
(17 / 10 / 2016)\end{array}$ \\
\hline Category: Hard news & Category: Soft news \\
\hline Total comments analyzed: 727 & Total comments analyzed: 339 \\
\hline Disqualified: 620 & Disqualified: 196 \\
\hline Qualified: 107 & Qualified: 143 \\
\hline
\end{tabular}

The quantitative data were collected 24 hours after each posting. In an attempt to identify the editorial decision about the newspapers' framing to the postings, we observed eight different sections: Politics, International, Economy, Sports, Culture, São Paulo, More and Supplement. It is worth mentioning that the section More involves various topics such as health, technology, sustainability, travel and news in Brazil. Within the More section, videos, photos and infographics are also available. The Supplement section encompasses the issues that in the print version of the paper come in the form of separate inserts, such as automobiles, included in the published set of periodicals. 
During both monitoring periods, it was noted that the comments that outnumbered shares were reactions to soft news $-70 \%$ of the 30 posts selected in 2015 and $63.8 \%$ of the posts selected in 2016. The sections that posted the most soft news were More and Culture, suggesting that, from the point of view of the paper, Facebook users are more interested in lighter news articles.

Hard news, however, stood out in the amount of participation by social network users. Graphics 1 and 2 allow us to compare the sections that posted the most during the monitoring period. It can be observed that the Politics section, with factual and controversial topics, posted the most in 2015, a predomination over the other sections (soft and hard news) that only increased in 2016.

Graphic 1. Posts by Estadão sections in 2015. (Self-elaboration)

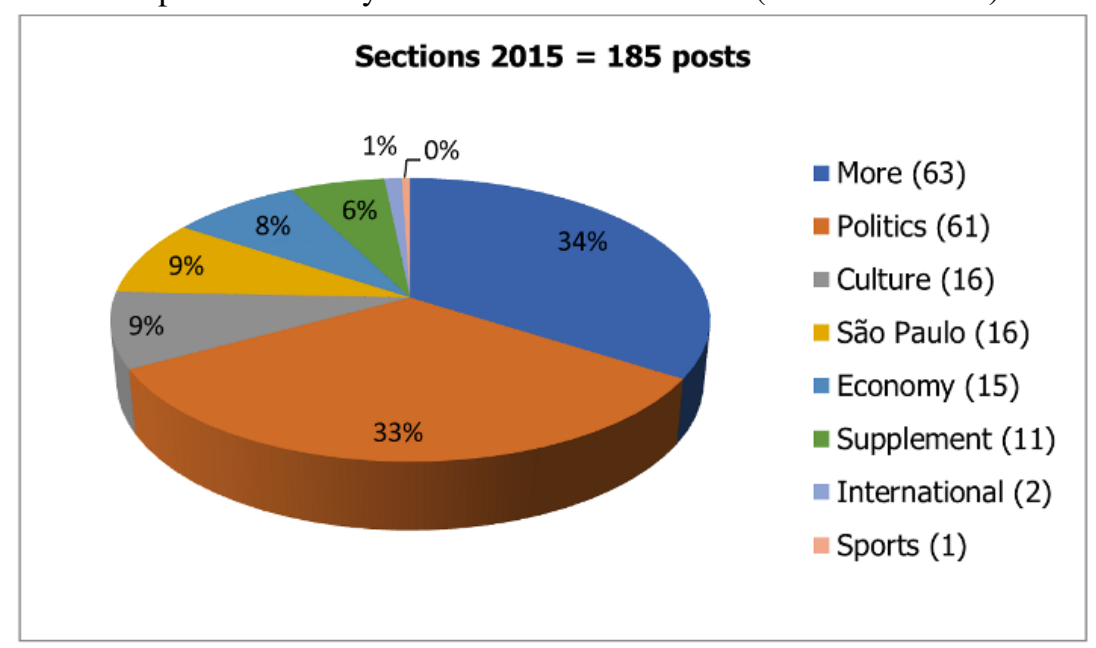

In 2016, there was a total of 71 posts in the Politics section, 35\% of the total. The pieces of news were largely of an informative nature, but there were 16 publications by columnists (opinion pieces). The second period of monitoring took place during a worsening economic, political and institutional crisis in post-impeachment Brazil. As shown in Graphic 2, the More section, even covering a broader range of topics in different formats, came in second, with a total of 52 posts, compared to 63 the previous year. 
Graphic 2. Posts by Estadão sections in 2016. (Self-elaboration)

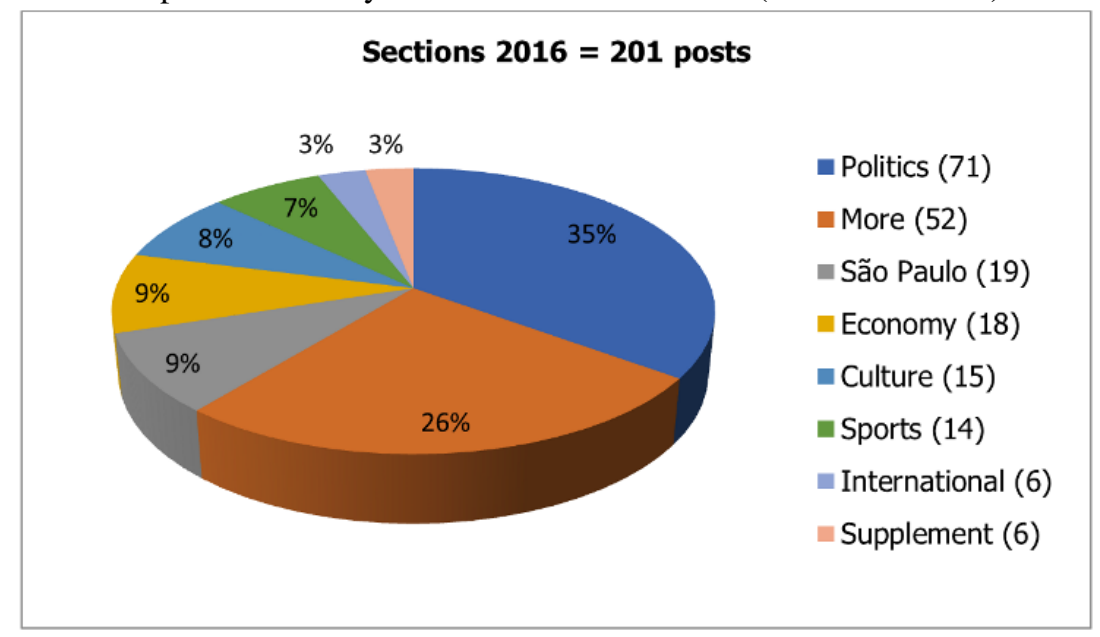

\section{Quality of the interactions in 2015}

Earlier in Table 1, we presented the post with the highest number of comments during our first monitoring period. The case of the janitor and the chief of police, posted on 14/10/2015 took on unimaginable repercussions, if we compare it with several decades ago when it would have been considered, by both the traditional press and the public who consumed such traditional media, as yet another piece of news on the inequality of life in Brazil. The example, taken as a real and documentary stratum of this research, shows the acceleration in human mediation with technology (Stiegler, 2010), but takes on value as an object of analysis of social products, produced in supposedly democratic public environments, in mediatized societies.

Following preliminary evaluation of the nature of the posts, the focus shifted to those comments that qualified as active, democratic and significant participation (Silverstone, 1999; Wolton, 2010). This did not include "comments on other comments" as the quantity identified and monitored went beyond the aims of the research. The comments were classified as qualified and not qualified, according to the basic criteria of rationality in public discussions. Thus, we discarded arguments based on beliefs, emotion and passion and did not include aggressive comments, personal attacks and foul language.

Next, each of the qualified comments was analyzed, aiming to categorize the framings shown. The analysis of the data collected in October 2015 identified three types of comments:

Type 1: Crime - Views for or against the police chief's attitude, taking into account legal arguments based on Brazilian Criminal Law;

Type 2: Context - References to political and economic issues of the Brazilian reality, directly quoting companies and individuals. General comments such as, for example, "but this police chief doesn't want to lock up that gang of politicians, does he?"- were not considered; 
Type 3: Surprise - Comments showing concern regarding the post, even questioning the newsworthy criteria adopted by the newspaper.

In post 1 , there was a greater incidence of Type 1 comments, whereas in post 2, the Context category stood out, as can be seen in Table 2. It is important to point out that, as presented in Table 1 , the post with the second highest number of comments in our initial monitoring was a following story related to the case of the cleaner and the chief of police, published on October 15, 2015. Post 2 was about a press interview in which the chief of Federal Police considered the case as "a breach of trust".

Table 2. Classification of the qualified comments in 2015. (Self-elaboration)

\begin{tabular}{ccc} 
Classification of comments & News item 1 & News item 2 \\
\hline Type 1: Crime & $53(48 \%)$ & $31(29 \%)$ \\
Type 2: Context & $34(31 \%)$ & $40(37 \%)$ \\
Type 3: Surprise & $24(21 \%)$ & $36(34 \%)$ \\
\hline
\end{tabular}

In the first post, what seemed to have the most impact on the audience was the information, positioning themselves for and against the cleaner, but also questioning the attitude of the authorities. A range of arguments were used, from those based on the law, to moral values and customs imposed by family. Comments judging the theft itself, regardless of the value of the object, were the most prevalent, condemning the theft of the sweet.

One user, for instance, commented that what should be discussed was the difference between theft and robbery.

[User A1] First, what happened here was theft, not robbery. Second, in Criminal Law there is the principle of insignificance, in which the derisory value of the object stolen means it does not constitute a crime. Thirdly, even without all that I just said, the law does not punish theft by a starving person of something to eat. Thus, she's an unfortunate victim of the selfishness of a materialistic person who is more concerned about a sweet than about another life. I prefer to see things as they really are: she wanted something to eat. Period. Maybe she never had enough money to buy imported sweets. And I would prefer to use my energy punishing those who really break the law, kill our children and rob the country, while laughing in our faces.

Another user questioned the imbalance of the measures taken by the police.

[User A2] In this case, what should be assessed is the lack of proportion of the measures taken. Yes, the cleaner was wrong to take something that was not hers. Where is the trust between employer and employee, in this case it ceased to exist when she took the sweet. In other words, the employee broke this trust. But she could have been given a verbal warning, or even changed positions with another employee, after what happened. But the guy all but called in the FBI for something that should be treated as a disciplinary matter. If only the authorities made the same efforts against drug trafficking or corruption. 
In the second post, a development of the initial news item, it can be seen that the readers were a little fed up about the topic of debate, using more aggressive expressions and questioning the importance of the publication. There were many attacks on the Federal Police for the police chief's attitude, many of which referred to the political and economic situation in Brazil and the naturalization of corruption there.

[User A3] A few years ago, two FP agents tortured and killed a Chinese citizen imprisoned in Galeao airport with a case containing 20 thousand DOLLARS. The money was never seen again... but nobody launched an investigation...

[User A4] This police chief should investigate the millions of Reais of niobium foreigners have stolen from Roraima, USA, ENGLAND, JAPAN ETC

It was also noted that the Brazilian context led many users to question journalistic ethics, including those of the Estadão itself:

[User A5] With the amount of corruption shown by the press, they expose the theft of a sweet. A Chilean once said to me: "Your press interviews gangsters and treats them like heroes", using the example of the singer Belo. And he's right.

Some even questioned the superficiality of the comments, arguing that the majority were carried away by the mere title, without even having read the content. This is something that has been stated by several researchers (Harcup \& O’Neill, 2016). Many of those who share links may not even be regular users of the news site and have just come across the news item via a link.

[User A6] The Federal Police reiterated that they have not launched a police inquiry "or any other investigative procedure regarding the occurrence on their premises." They also report that there have been no arrests and no one has even been detained. If people actually read the material they would see the huge gap between the sensationalist title and the content of the news item.

\section{Quality of interactions in 2016}

One year after the initial empirical research, we began a new round of analysis on the page of Estadão on Facebook. We found very different types of posts, news and comments. In 2015 the non-qualitative participation by users was very high. In 2016, there was a significant difference between qualitative and non-qualitative participation. Actually, in our 2016 monitoring we noticed an inversion, as well as a low number of non-qualitative comments.

As for the post, "Students handcuffed by municipal police in protest against the minister of education", with the highest number of comments as shown in Table 1 (total of 377), the categories that emerged for qualifying the comments were organized as follows:

Type 1: Political debate - The discussions went beyond the central issue of the news item, reprimanding the demonstrators, and focused on political party issues, similar to the "Context" category of the 2015 analysis. There were 53 comments in this category (15\% of the total), as in the example below: 
[User B1] I can't believe what I'm reading in these comments. Are adults really acting as fascist agents of oppression? Do the children of these commentators really study in comfortable private schools that give them a guaranteed spot in federal and state universities, and so the rest are bums and troublemakers? Really?? I'm flabbergasted with this nation that only wants order and progress for the children of the poor.

Type 2: Statements in favor or against the attitude of the police - Comments focusing exclusively on the central fact of the news item. In the cases in which this attitude also included some kind of statement about politics, the comment was placed in the previous category. This was the category with the largest number of comments, 249 (69\% of the total), and some examples include:

[User B2] Take a stick to them, they don't even think about actually studying, which would be the right thing to do?... I bet they don't even know what they're demonstrating about, and there's probably some coward behind it, urging them on, who doesn't want to show his face... they got what they were after... hahah

[User B3] That's just what they were looking for, to make themselves into victims, protesting against the Government that just adjusted the Fies [student loan system].

Type 3: Criticism of the press - Debates on how the report was slanted and written. A total of 60 comments ( $16 \%$ of the total).

[User B4] Seven students detained after confronting the Municipal Guard (MG). The Municipal Guard claims that the demonstrators stoned the MG cars, breaking the windscreen of one, and a guard was hit by a stone, according to the MG. It's obvious that whoever wrote the title is either high or so biased towards the "student" victim that they class the MG action as unwarranted and unprofessional. The police were more than correct, congratulations to the firm for taking control of these so-called victims of society.

[User B5] Brazilian journalism is the worst in the world. It's disgusting to see the amount of leftism per $\mathrm{m} 2$ in their writing.

In the second most commented post of October 2016, entitled "Jon Bon Jovi can't stand singing hits ...", we found a high level of disqualified comments - reaching 196 comments $(57,8 \%)$ out of a total of 339 analyzed in this stage of the research. One reason of this finding may have to do with the nature of the post, soft news, originating from an interview the singer gave in Brazil before one of his concerts. Comments that were classified as qualified were related to:

Type 1: Humor/Sarcasm - Comments referring to other artists who were one-hit wonders, users making fun of friends and family members who like the songs and the old hits. This category predominated, with 64 comments ( $45 \%$ of the total), although many were short and shallow ones.

[User C1] Hahahaha ... but you'll be singing it forever Jon!

[User C2] Just like Bruno can’t stand singing "Dormi na praca”... 
Type 2: Cultural Criticism - Approaching economic inequality, users expressed their opinions about the artist's snobbishness, the fortune he has made and comments about other celebrities who like to complain. There were 49 comments ( $34 \%$ of the total).

[User C3] Go to Africa and see people dying of hunger. That depresses me.

[User C4] That admission really depresses thousands of fans. I don't know if I'd pay to see a 30-year-old band knowing that their hit wouldn't be sung with heart. This Jon Bon Jovi is a big snob.

Type 3: Solidarity - Users who understand and agree with Jon Bon Jovi's statement, totaling 30 comments ( $21 \%$ of the total).

[User C5] I really think he had to make room for other songs that the fans would like to hear live, but it never happens because he has to repeat the famous ones... I went to the last concerts and some five songs from each were unnecessary because there are others much better and cooler.

[User C6] He also has no voice. The song demands a lot for someone over 35 years of road.

[User C7] I agree with the guy. The problem is that the audience loves "classics" and just wants to hear the same old songs. That must be the difference, the guy makes good music until today.

If we put the collected data in comparison, in order to answer our research question, in general, we can say that Brazilian consumers of information on the Estadão Facebook page seem to value news, no matter its significance, and feel like making comments related to the troubled political atmosphere and systemic economic corruption in the country.

According to the period studied of October 2015, from the selected 185 posts of the Estadão newspaper, only $38 \%$ of the 1,195 comments were considered to be qualified. These comments were related to the same subject, as a reaction to two posts concerning the case of an officer janitor who ate a police officer's sweets. The posts did not bring anything new to the Brazilian scene, considering the serious, chaotic, economic and political crisis at the time. Although the topic was irrelevant, it gained a disproportional repercussion online.

One year later, data revealed completely different evidence. Although there were more posts on the Estadão page on Facebook, totaling 201, there were considerably fewer comments. We found one hard news post which received the highest number of comments concerning students' protests. The second highest number of comments was to soft news post. Among the $377 \mathrm{com}-$ ments related to hard news, $96 \%$ were considered qualified by our criteria. As to the Jon Bon Jovi soft news post, $42 \%$ of 339 comments were qualified.

Our second year of data collection found that Brazilians were not only used to experiencing a major political and economic crisis, but also were sick and tired to listening to, talking about and commenting on news concerning the operation Car Wash investigations. 


\section{Conclusion}

The search for analytical tools to allow us to better understand quality of participation among news users of online legacy media is the issue raised by this article.

It exams the quality of interactions by readers of the centennial Brazilian newspaper Estadão on its Facebook page, differentiating them from practices that contributed nothing to the public debate in democratic principles.

Our findings between 2015 and 2016 in Brazil, actually, pose more questions than answers suggesting that we have a long way to go on in our studies. For example, we could ask why the percentage of qualified comments reversed. Were people presenting more rational arguments than before? If not, how can we examine and understand online audiences better? Should we go back to study structures of feeling?

The study aimed to contribute to discussions and pursue qualitative tools to allow us to better understand fundamental issues posed to journalistic scholars in a time of an excess of information creating chaos, naivety, disorientation, vigilance and new forms of belonging and power under dispute.

\section{REFERENCES}

Carlson, M. \& Lewis, S. (2015). Boundaries of journalism: Professionalism, practices and participation. London: Routledge.

Carro, R. (2016). Brasil. Digital News Report 2016 (pp. 82-83). Oxford: University of Oxford Press.

De Santi, A. (June 2015). O lado negro do Facebook. Revista Superinteressante, (348): 28-39.

Gillespie, T. (2014). The relevance of algorithms. In T. Gillespie, P. Boczkowski \& K. Foot (eds.), Media technologies: essays on communication, materiality, and society (pp. 167194). Cambridge, MA: MIT Press.

Gomes, W. (2014). Esfera pública política. In A. Citelli, C. Berger \& M. A. Baccega, Dicionário de Comunicação: escolas, teorias e autores (pp. 221-229). São Paulo: Contexto.

Gomes, W. \& Maia, R. (2008). Comunicação e democracia. São Paulo: Paulus.

Habermas, J. (1997). Direito e democracia. Rio de Janeiro: Tempo Brasileiro.

Harcup, T. \& O'Neill, D. (2016). What is News? News values revisited (again), Journalism Studies. Doi: 10.1080/1461670X.2016.1150193

Hjarvard, S. (Jan-Jun de 2012). Midiatização: teorizando a mídia como agente de mudança social e cultural. Matrizes, 5(2): 53-91.

Jenkins, H. (Jan-Abr de 2016). Convergência e conexão são o que impulsionam a mídia agora. Entrevista concedidada a Priscila Kalinke e Anderson Rocha. Revista Brasileira de Ciências da Comunicação - Intercom, 39(1): 213-219.

Johnson, T. S. (2015). Entre hard e soft news: explorando modelos de personalização de notícias em plataformas sociais. Lumina, 9: 1-18. Source: https://lumina.ufjf.emnuvens.com.br/lumi na/article/view/479 
Lorenz, M. (2014). Personalização: análise aos 6 graus. In J. Canavilhas, Webjornalismo: 7 características que marcam a diferença (pp. 137-145). Covilhã: Libros LabCom.

Mager, A. (2011). Algorithmic Ideology: how capitalist society shapes search engines. Conference paper for "A Decade in Internet Time"@OII. Oxford: Oxford. Accessed on December 05, 2016, available at http://ssrn.com/abstract=1926244

Manovich, L. (1999). Database as symbolic form. Convergence: The International Journal of Research into New Media Technologies, 5(2): 80-99.

Martino, L. M. (2015). Teorias das mídias digitais. Petrópolis-RJ: Vozes.

Mitchell, W. \& Hansen, M. B. (2010). Introduction. In W. J. Mitchell \& M. B. Hansen, Critical terms for media studies (pp. vii-xxii). Chicago: The University of Chicago Press.

Portal da Imprensa. (2015). Estudo revela que "Estadão"é o veículo mais acessado pelos brasileiros na internet. Portal da Imprensa. Accessed on December 10, 2015, available at www.por atlimprensa.com.br/noticias/brasil/72954/estudo+revela+que+estadao+e+o+veiculo+mais+a cessado+pelos+brasileiros+na+internet

Primo, A. (2007). Interação mediada por computador: comunicação, cibercultura, cognição. Porto Alegre: Sulina.

Ramirez, P. A. (2016). Mediatizácion social: poder, mercado y consumo simbólico. Salamanca: Comunicación Social (CS).

Reuters Institute for the Study of Journalism. (2016). Digital News Report 2016. Oxford: Reuters Institute. Source: www.digitalnewsreport.org

Rost, A. (2014). Interatividade: definições, estudos e tendências. In J. Canavilhas, Webjornalismo: 7 características que marcam a diferença (pp. 53-88). Covilhã: Livros LabCom.

Silva, G. (2013). Para pensar critérios de noticiabilidade. In G. Silva, M. P. Silva \& M. L. Fernandes, Critérios de noticiabilidade: problemas conceituais e aplicações (pp. 51-69). Florianópolis: Insular.

Silverstone, R. (1999). Por que estudar a mídia?. São Paulo: Loyola.

Sousa, P. J. (2002). Teorias da notícia e do jornalismo. Chapecó: Argos.

Stiegler, B. (2010). Memory. In W. J. Mitchell \& M. B. Hansen, Critical terms for media studies (pp. 64-87). Chicago: The University of Chicago Press.

Wolton, D. (2010). Informar não é comunicar. Porto Alegre: Sulina.

Woolley, S. C. (April de 2016). Automating power: social bot interference in global politics. First Monday, 21(4): 1-13. Source: http://firstmonday.org/ojs/index.php/fm/article/view/6161/53 00 